\title{
New Koinonia Epistemology in the Digital-Based Christian Theology
}

\author{
Sonny Eli Zaluchu \\ \{sonnyzaluchu@stbi.ac.id\} \\ Sekolah Tinggi Teologi Baptis Indonesia Semarang
}

\begin{abstract}
Koinonia is a concept explaining communion or fellowship in the theology of Christian. After the era of the Internet of Things, the communion pattern has shifted from a direct relationship involving physical presence to an indirect relationship where the internet and all of its products exist among humans. Therefore, it is necessary to build a new conception of digital koinonia. This paper aims to explain the digital koinonia concept and the reasons behind its presence contemporarily. This writing uses library studies and concludes that digital koinonia with its characteristics following the logic of media and the internet is a new epistemology demanding theological reconstruction.
\end{abstract}

Keywords: Koinonia; Fellowship; Internet Of Things; Christian Theology; Digitalization

\section{Introduction}

Communion or fellowship is one of the characteristics of Christian epistemology. Through fellowship, the relationship among the congregation is intertwined through the interaction happening. This has lasted for a long time and has become part of the church's history, particularly in the implementation of rites, rituals, and other various religious activities. I call this traditional fellowship because it takes place in the face-to-face concept and requires physical presence together in a specific location, at a particular time, for a certain interest. The point is that the Christian followers meet to do spiritual activities, do religious rituals, or interact socially, and that is how the communion or fellowship is formed.

However, this traditional fellowship pattern faces external challenges. All over the world nowadays moves homogenously toward digitalization. With surprising speed, change happens every time. Technological disruption presenting digitalization in all aspects of life also affects how Christian followers carry out their religious lives. The demand for such modification is not easy because the Christian religious institution and its practice of rites, rituals, and spiritual activities have rooted very much in the tradition and history. Therefore, in her research, Cloete (2015) proposed the importance of the Christians to formulate the reflection of a new theology in the digital cultural context as the unique spiritual ecosystem. In addition to building the philosophical foundation, Crumpton provided a more practical proposal. According to him, the philosophical foundation can be contemplated progressively.

What is more crucial is transforming the church and all its spiritual activity apparatus to get out of the traditional pattern centralized in a building and become digital ultimately as the 
response toward the urgent demand of change (Crumpton 2018). This is in line with the opinion of Hutching (2011), stating that in this contemporary world, the religious community has already been living in the digital culture, so that the religious institutions have no other choice but to leave the traditional environment and make an adaptation. The research conducted by Dwirahardjo (2020) concluded that the shift from the spiritual activities done in the church to be performed online is the best response right now. With online spiritual activities, people can do them at home or anywhere (Woods 2013). From those various thoughts above, the demand toward church digitalization becomes something unavoidable. Its realization is not only in the facilities and infrastructure or in the shift of rites and rituals but also in the philosophical-theological foundation. Those two are needed. There is no other way for the church to survive in the digitalization flow except to adjust itself and have the courage to step out of the traditional boundaries.

Everybody around the world currently, including the religious followers, has lived in the digital culture. Humans are more connected with fellow humans online by using the internet connection. Online applications have become the primary tool of humans to carry out their lives. Regarding the spiritual needs, the shifts have been made. Significantly during this pandemic era, the church has wholly shifted its services into online services. The meetings for spiritual activities that were centralized in a church building now have been conducted at the home of every congregation with an internet connection. The prayers and spiritual activities are conducted online via Zoom or digital content broadcast on YouTube. Suddenly, the fellowship built among Christian followers has been shifted to become a digital fellowship.

The importance of accepting and implementing digital fellowship as a theological truth in the Christian fellowship is the main argument in this research. It is the right moment for the church to stop suspecting change as a threat ruining the traditional theological order and accepting the new changes by making significant adjustments. This paper will first discuss the fellowship in the koinonia concept. Second, the article will explain the internet of things and its influence in the koinonia to build a digital koinonia epistemology.

\section{Results and Discussion}

\subsection{Koinonia}

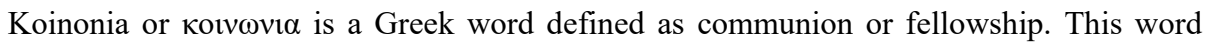
derives from the word 'koine' having a basic form 'koinos.' Wahyu (2013) stated that the word 'koine' explains a similar and common thing. The use of this word is generally explaining the establishment of a community united by a common interest. In the Hellenistic era, this word referred to a group of people that had fun together, like the people watching entertainment in theaters. In Greek culture, the theater was not only a name of a place, but it had a social function where all people could interact in watching a show.

The term was adopted by Christianity, referring to the characteristics in the early church community in Jerusalem (Falk 1995). One of its characteristics is to build a close fellowship with one another (Zaluchu 2018). The fellowship is described in the way the early community conducted religious rites (tearing the bread together), became united in the Apostles' teachings, and cared for one another. Furthermore, the fellowship is participatory, where all members in a fellowship form a covalent bond. Even according to Berkhof \& Enklaar (2005:11). The fellowship in the early church was the habit of spiritual activities by gathering on Sundays by praying, singing, and listening to the explanation of God's commandment and 
holding a banquet. This concept then developed into one of the Christian epistemology forms explaining the establishment of Christian people gathering because they have the same purpose in the faith and belief through a worship. From that understanding, the word fellowship is finally associated with Christian worship. However, this word has a broader meaning than just gathering together for worship because it covers any spiritual activities conducted in the Christian functions.

In a broader concept, koinonia can be explained through the thought of Wright (1988:372), stating that the definition of koinonia can be formulated with the reason behind participation in spiritual activities or worship. According to him, koinonia is close with the establishment of similar thinking and points of view. Personal relationships among Christian followers or communities are established due to participation in the same neighborhood and reality. Thus, it can be concluded that koinonia is not just a physical fellowship but also covers all participatory functions of Christian people in implementing their thinking and points of view jointly with other Christian people, via whatever the media is.

\subsection{Internet of Things and its Influence in Koinonia}

According to Kranz, the Internet of Things (IoT) is not just the operation of the internet and digitalization in all aspects of life. The central theme contained in the IoT is the change and transformation that shift the conventional ways into a new format named data. All those data are mutually interconnected in a digital machine capable of moving automatically, switching over independently and smartly without the interference of humans (Kranz 2019:46). In other words, IoT is an era where a digital machine is connected with other digital devices in a network. In this concept, humans, trading goods, letters, books, pictures, documents, or any items are changed into a form of big data and can be transferred with high speed exceeding space and time (Hashem et al., 2015). However, what is interesting from the opinion of Kranz is the conclusion stating that in IoT, in all its processes, the people involved and the traffic of the data are mutually integrated and capable of changing information to become actions (Kranz 2019:14). Hence, as long as everything can be digitalized, IoT is capable of connecting anything with anything.

One of the changes caused by IoT is related to space and time. The presence of cyberspace has made space and time borderless (Le Duc 2015). The digital world has presented the borderless and bottomless realm. If it is implemented in religious life, it means that someone can do spiritual activities when the person is in the virtual space of the church. However, that person is not present physically in a building as it has been done conventionally. Thus, there are significant differences between conventional spiritual activities and online spiritual activities in terms of presence and existence. Moreover, when related to space existence, cyberspace and all things going on in it have become a new reality in the way humans do their activities and implement faith and their spiritual lives. Cyberspace becomes a new social space that redefines how humans socialize or interact to conduct spiritual activities.

The fellowship of the believers in the conventional understanding is the physical presence and direct interaction; nevertheless, with IoT's reality of a new digital space, direct exchange and physical presence experience transformation. According to Spadaro (2014:46), the church needs to rethink the definition of interconnection in the concept of koinonia. This thinking is reasonable because if someone is present physically in a room but not connected, it is not a fellowship but solitude. The same thinking can be applied in the digital spiritual space. A koinonia will only be formed when people in the digital room are not merely present but also 
mutually connected in a digital community (Tamí-Maury et al., 2017). Therefore, the emotional experience can still be maintained.

The proliferation of media and the emergence of various digital platforms have created new patterns considered normal in virtual relations (Sherlock 2013). The unique designs can be seen from the shift of the term and the shift of the meaning of the interpersonal relationship. The practice of koinonia in the physical presence introduces the naming of a best friend, a sibling, a brother, a partner, or a sister. However, all that vocabulary has changed in semantics and meaning. The interconnection in the digital concept is valued more from the interests and reasons behind why someone is connected with other people. For example, in social media, the interconnection is represented by the vocabulary 'friend', which changes into 'follower' when the relationship intensity increases. A similar thing happens in digital content as the term 'viewers' has changed to become 'subscribers' when it is carried out to the commitment level. Thus, it can be concluded that digital koinonia has new ways to define interpersonal relationships by following IoT's logic and procedure.

\section{Conclusion}

Finding characteristics that are similar to traditional koinonia in cyberspace and virtual communities is a useless effort. The connection meaning in the digital koinonia is far different from that of conventional because the digital media logic itself influences it. The quality between the two cannot also be compared, and each has its strengths. The realm fellowship in Christianity no longer relies on a building but also has shifted to digital space. The interconnection is measured from the aspect of interest through various existing media platforms. Different from the traditional koinonia where there is direct contact, what is called direct contact in the digital fellowship is when people with the same understanding gather together and are present in the same networking for the same interest. Therefore, the church is challenged to formulate and reconstruct the koinonia epistemology following the situation of the current era.

\section{Acknowledgments}

Fotarisman Zaluchu, Ph.D. from the University of North Sumatra Medan, and Dr. Robinson Rimun from STT Baptist Indonesia have read and provided insight and critical analysis of this paper.

\section{References}

[1] Cloete, Anita L. 2015. "Living in a Digital Culture: The Need for Theological Reflection." HTS Teologiese Studies / Theological Studies 71(2). doi: 10.4102/hts.v71i2.2073.

[2] Le Duc, Anthony. 2015. "Cyber/Digital Theology: Rethinking About Our Relationship with God and Neighbor in the Digital Environment." Religion and Social Communication 13(2):132-58.

[3] Dwiraharjo, Susanto. 2020. "Konstruksi Teologis Gereja Digital: Sebuah Refleksi Biblis Ibadah Online Di Masa Pandemi Covid-19 [Digital Church Theological Construction: A Biblical Reflection on Online Worship in the Time of the Covid-19 
Pandemic]." EPIGRAPHE: Jurnal Teologi Dan Pelayanan Kristiani. doi: 10.33991/epigraphe.v4i1.145.

[4] Hashem, Ibrahim Abaker Targio, Ibrar Yaqoob, Nor Badrul Anuar, Salimah Mokhtar, Abdullah Gani, and Samee Ullah Khan. 2015. "The Rise of 'Big Data' on Cloud Computing: Review and Open Research Issues." Information Systems 47:98-115. doi: 10.1016/j.is.2014.07.006.

[5] Hutchings, Tim. 2011. "Contemporary Religious Community and the Online Church." Information Communication and Society 14(8):1118-35. doi: 10.1080/1369118X.2011.591410.

[6] Sherlock, Alexandra. 2013. "Larger Than Life: Digital Resurrection and the ReEnchantment of Society." The Information Society 29(3):164-76. doi: 10.1080/01972243.2013.777302.

[7] Tamí-Maury, Irene, Louis Brown, Hillary Lapham, and Shine Chang. 2017. "Community-Based Participatory Research through Virtual Communities." Journal of Communication in Healthcare 1-7. doi: 10.1080/17538068.2017.1337604.

[8] Woods, Orlando. 2013. "Converting Houses into Churches: The Mobility, Fission, and Sacred Networks of Evangelical House Churches in Sri Lanka." Environment and Planning D: Society and Space 31(6):1062-75. doi: 10.1068/d7912.

[9] Zaluchu, Sonny Eli. 2018. "Eksegesis Kisah Para Rasul 2:42-47 Untuk Merumuskan Ciri Kehidupan Rohani Jemaat Mula-Mula Di Yerusalem [Exegesis of Acts 2:42-47 to Define the Characteristics of the Spiritual Life of the Early Christian Community in Jerusalem].” EPIGRAPHE: Jurnal Teologi Dan Pelayanan Kristiani 2(2):72-82. doi: 10.30648/dun.v2i2.172.

[10] Berkhof, H., and L. H. Enklaar. 2005. Sejarah Gereja. 21st ed. edited by Staf Redaksi BPK Gunung Mulia. Jakarta: BPK Gunung Mulia.

[11] Crumpton, Valerie E. 2018. "The Church Has Left the Building: A Leadership Perspective of Online Church versus Traditional Church." Portland Seminary, George Fox University, Portland, Oregon.

[12] Kranz, Maciej. 2019. Building the Internet of Things. 1st ed. Jakarta: Elex Media Komputindo.

[13] Spadaro, Antonio. 2014. Cybertheology: Thinking Christianity in the Era of the Internet. New York: Fordham University Press.

[14] Wright, D. .. 1988. "Koinonia." New Dictionary of Theology 372.

[15] Falk, Daniel K. 1995. "Jewish Prayer Literature and the Jerusalem Church in Acts." Pp. 267-301 in The Book of Acts in Its First Century Setting, edited by R. Bauckham. Grand Rapids: William B. Eerdman s Publishing Company.

[16] Wahyu, Rita. "Koinonia - Persekutuan - Fellowship.” Sarapan Pagi Biblika. Accessed August 20, 2021. http://www.sarapanpagi.org/koinonia-persekutuan-fellowshipvt6304.html. 